cates were operating within the limited political space available during the 1980s, forced to creatively adjust goals and compromise when necessary to ensure the existence of training programs.

Slatin bolsters this narrative through the use of union documents, government publications, and interviews with union members and health and safety professionals, making his account of the development of worker health and safety legislation and training programs the strongest part of the book. The political component of this work is somewhat less developed. Slatin's examination of the political economy of the work environment provides a cursory glance at the motives and actions of labour, health professionals, management, and the state, adding a short discussion of the impact of social movements. Integrating more of the growing literature on deindustrialization, deregulation, and the environmental justice movement would have improved this section by demonstrating the specific forces aligned against the regulatory and training efforts of labour and extending this analysis to encompass the impact of these changes on employment, union membership, and working class communities.

A similar critique can be made of Slatin's emphasis on the difficulties the union movement faced when confronted by neoliberal attacks and the increasing mobility and political influence of corporations. Slatin does not sufficiently address examples of what the neoliberal restructuring of the New Deal order meant for the workplace health and safety movement, and a more direct approach to these very real dangers facing the labour movement would have strengthened his argument. Instead, the rising tide of deregulation, along with the response and actions of management, persistently lurk in the background, emerging at the end of each chapter only to reiterate the influence of these forces at the expense of a clear definition of how this movement experienced neoliberal reforms.

Slatin's refreshing political directness makes this book of interest to academics, health and safety professionals, and activists interested in a policydriven account of "the limitations of reforming capitalism at the expense of the ongoing degradation of human health and environmental sustainability" (7). Environmental Unions fills an important place in the literature on this topic, and provides a useful starting point for social and cultural historians interested in this field.

Michael J. Murphy

Stony Brook University

Harvey Schwartz, Solidarity Stories: An Oral History of the ILWU (Seattle: University of Washington Press, 2009).

Solidarity Stories is the culmination of nearly three decades of interviews with 
International Longshore and Warehouse Union (ILWU) members, many of which were conducted by the book's editor, Harvey Schwartz (all but one of the book's interviews have previously appeared in the union's newspaper, The Dispatcher). The curator of the oral history collection at the ILWU library in San Francisco and an oral historian at the Labor Archives and Research Center at San Francisco State University, Schwartz hopes "that this book and the vision it reflects will prove informative, useful, and even inspiring to unionized and nonunionized workers alike, to labor activists, teachers, students, and researchers, and to all those other interested good people outside the labor and academic communities" (8). The result is an accessible and engaging account of one of the most progressive and democratic unions in the American labour movement and the men and women who worked along the North American west coast and in Hawaii throughout much of the twentieth century.

In Schwartz's capable hands, the interviews collectively tell the story of the ILWU from the perspective of union luminaries such as Harry Bridges, Louis Goldblatt, and Jack Hall as well as that of the rank-and-file activists who built the union from the bottom up. The interviews are mostly organized geographically into six chapters that cover the San Francisco Bay Area docks, the Los Angeles and Long Beach Harbours, the ports of the Pacific Northwest and Canada, the inland warehouses and cotton compresses of California, and Hawaii's plantations. The final chapter, consisting of interviews with three prominent ILWU activists who at one time belonged to the Communist Party (CP), explores the Old Left's contribution to the union. The chapters themselves unfold chronologically, guiding the reader through more than seven decades of ILWU history. Certain events that will be familiar to students of labour history and the ILWU, such as the 1934 waterfront strike, loom large. But numerous less-celebrated battles, such as the fight to eliminate asbestos from the San Francisco waterfront in the 1970s and the successful organizing drive at Powell's Books in Portland, Oregon at the end of the twentieth century, also figure prominently in Solidarity Stories. Within each chapter, Schwartz has also done a skillful job weaving the first-hand accounts into a strong narrative in the tradition of Studs Turkel. He has removed the interviewer's questions and edited most of the excerpts into concise passages of a few pages or less.

Several overarching themes give cohesion to the book's six chapters and myriad of individual reminiscences. African American, Mexican American, and Filipino members discuss their struggles against racial discrimination and the union's role in advancing the cause of civil rights in the workplace as well as in the community at large. Female members recall the distinct challenges they faced and underscore the vital leadership that women have provided the ILWU throughout its history. Numerous members also speak to the union's radicalism and social progressivism more generally, as well as the implications of its suspected ties to the CP. 
Perhaps the most powerful theme in Solidarity Stories is dignity; that is, the immense pride and self-respect that the ILWU has brought its members. The book contains vivid first-hand accounts of the harsh and unfair working conditions that prevailed in the warehouses, fields, and on the docks before the ILWU came along. Although the 1934 strike remains a source of pride among its members, they seem equally proud of the wages, health and safety provisions, and influence that the ILWU has earned them ever since. "Every time I go to the hospital, or up to the clinic, or have to get some medicine, I think, 'Thank God for Harry Bridges and the ILWU,"' explains Jerry Tyler, a Local 19 veteran in Seattle (119). Cleophas Williams, formerly of Local 10 in San Francisco, puts it this way: "We're talking about a union that gave you a chance to be somebody, to hold your head high" (51). Such sentiments are echoed throughout the book. Yet after reading the accounts of Tyler, Williams, and the other union members whose stories who fill these pages, it is clear that they have themselves to thank just as much as Bridges.

Solidarity Stories will prove a valuable resource for graduate and undergraduate students of labour and working-class history and is a superb introduction for anyone interested in learning about the ILWU. Not only does the book provide a diverse grassroots perspective for the entire scope of ILWU history, but Schwartz also supplies concise summaries of key events, a background of its locals, and a glossary of terms for those unfamiliar with the industry's lexicon. Some may find the book's tone over-celebratory; indeed, one will not find much criticism of the ILWU in this collection. This stems in part from the members who have made themselves available for interviews and Schwartz's intent to inspire present-day activists. Yet it is also a reflection of the fierce loyalty that the ILWU has earned from its members. As Schwartz discloses in his introduction, "This oral history of the ILWU largely represents the voices of all those rank-and-file members who have supported the union with vigour, pride, and passion for past seventy-five years" (3).

John J. Rosen

University of Illinois at Chicago

\section{Cheryl R. Ganz, The 1933 Cbicago World's Fair: A Century of Progress (Urbana and Illinois: University of Illinois Press, 2008).}

This is a highly analytical social and cultural history of the 1933 Chicago World's Fair containing many wonderful illustrations. Giving ample attention to the fair's business and organizational underpinnings, Cheryl Ganz focuses on the multiple meanings behind the spectacle, differing from organizers to audience and beyond. Accordingly, she opens and concludes with Sally Rand, the scandalous fan-dancer who became the icon of the fair. Determined to succeed despite 